\title{
PENGETAHUAN GIZI REMAJA SMPN 40 KOTA BANDUNG
}

\author{
Irma Darmawati ${ }^{1}$, Sela Arumiyati ${ }^{2}$ \\ Sekolah Tinggi Ilmu Keperawatan PPNI Jawa Barat, Bandung, Indonesia \\ Email: irma_darmawati87@yahoo.com
}

\begin{abstract}
ABSTRAK
Pengetahuan gizi dapat menentukan status gizi dan perilaku remaja dalam memilih makanan. Peningkatan prevalensi masalah gizi di Indonesia tidak hanya sebatas masalah gizi kurang namun juga sudah bertambah menjadi beban ganda gizi lebih. Prevalensi masalah gizi lebih pada remaja umur 1315 tahun di Indonesia sebesar 10,8\%, terdiri dari 8,3\% overweight dan 2,5\% obesitas. Penelitian dilakukan untuk mengetahui gambaran pengetahuan gizi yang dimiliki oleh remaja dengan menggunakan metode deskriptif yang bertujuan untuk mengetahui gambaran pengetahuan remaja tentang status gizi di SMPN 40 Kota Bandung. Didapatkan jumlah sampel sebanyak 89 orang dengan menggunakan teknik Proporsional Random Sampling. Analisa pengetahuan dilakukan melalui distribusi frekuensi. Hasil penelitian di SMPN 40 Kota Bandung menunjukkan remaja berpengetahuan baik 48 orang $(53,9 \%)$, cukup 22 orang $(24,7 \%)$, kurang 19 orang $(21,3 \%)$, dengan poin paling tinggi didapatkan pada kategori pengetahuan tentang status gizi lebih yaitu 81 orang $(91,0 \%)$. Poin terendah didapatkan pada kategori cara penilaan status gizi yaitu 53 orang $(59,6 \%)$. Pihak sekolah diharapkan lebih memperhatikan dan memberikan pendidikan tentang pengetahuan gizi dan status gizi. Bagi pelayanan kesehatan diharapkan lebih sering melakukan monitoring dan pembinaan UKS serta PMR di sekolah.
\end{abstract}

Kata kunci: Gizi, Remaja, Status Gizi.

\author{
PENGETAHUAN GIZI REMAJA SMPN 40 KOTA BANDUNG \\ Irma Darmawati ${ }^{1}$, Sela Arumiyati ${ }^{2}$ \\ Sekolah Tinggi Ilmu Keperawatan PPNI Jawa Barat, Bandung, Indonesia \\ Email: irma_darmawati87@yahoo.com
}

\begin{abstract}
Nutritional knowledge can determine the nutritional status and the behavior of teenagers in choosing food. The increase in the prevalence of nutritional problems in Indonesia are not only limited to less nutritional problems but has also increased to the double burden of malnutrition. The prevalence of nutritional problems is more on teen aged 13-15 years in Indonesia amounted to $10.8 \%$, comprising $8.3 \% 2.5 \%$ overweight and obesity. Research was conducted to find out the description of the nutritional knowledge owned by teens by using descriptive method which aims to know the description of knowledge about adolescent nutritional status in 40 SMP Bandung. The number of samples obtained as many as 89 people using Proportional Random Sampling techniques. Analysis of the frequency distribution is done through knowledge. Research results shows 40 adolescents knowledgeable good 48 people $(53.9 \%)$, just 22 people $(24.7 \%)$, lack of 19 people $(21.3 \%)$, with the highest points are obtained on a category of obesity about 81 people $(91.0 \%)$. The lowest points are obtained on the category how to measure the nutritional status about 53 people $(59.6 \%)$. The school is expected to pay more attention to and provide education about knowledge of nutrition and nutritional status. For the ministry of health expected more frequent monitoring and coaching the UKS and PMR on the school.
\end{abstract}

Keywords: Adolescents, Nutrition, Nutritional Status. 


\section{PENDAHULUAN}

Remaja merupakan kelompok peralihan dari anak-anak ke dewasa dan merupakan kelompok yang rentan terhadap perubahan-perubahan yang ada di lingkungan sekitarnya, khususnya pengaruh pada masalah konsumsi makanan. Adapun kebiasaan remaja terhadap makanan sangat beragam seperti bersifat acuh terhadap makanan, lupa waktu makan karena padatnya aktivitas, makan berlebih, mengikuti trend dengan makan fast food dan sebagainya, tanpa memperhatikan kecukupan gizi yang mereka butuhkan (Hendrayati, Salmiah, \& Rauf, 2010).

Tingkat pengetahuan gizi seseorang berpengaruh terhadap sikap dan perilaku dalam memilih makanan yang pada akhirnya akan berpengaruh pada keadaan status gizi seseorang. Semakin tinggi tingkat pengetahuan gizi seseorang diharapkan semakin baik pula keadaan status gizinya (Ringga, 2011).

Studi yang dilakukan di berbagai negara di daerah Asia Tenggara, mengungkapkan bahwa kurangnya pengetahuan tentang status gizi mempengaruhi hampir semua parameter pertumbuhan dan ukuran tubuh yang mengakibatkan kekurangan gizi dan kelebihan gizi (Haider, 2006). Tetapi tidak jarang pula pendidikan mempengaruhi pengetahuan status gizinya sebab bisa saja orang tersebut rajin mendengarkan informasi dan penyuluhan gizi maka tidak mustahil pengetahuan gizinya akan lebih baik. Pengetahuan gizi ini selanjutnya akan menentukan status gizi dan perilaku dalam memilih makanan (Mutmainnah, Dachlan, \& Nawir, 2013).

Masalah yang menyebabkan gizi salah adalah tidak cukupnya pengetahuan gizi dan kurangnya pengertian tentang kebiasaan makan yang baik. Penelitian yang dilakukan oleh Asmini (2008), mengenai pengetahuan gizi seimbang dengan status gizi remaja pada siswa Madrasah Tsanawiyah didapatkan bahwa yang mempunyai pengetahuan gizi baik $54,21 \%$ dan status gizi baik $57,31 \%$. Penelitian lain yang dilakukan oleh Junus (2003), yang berhubungan dengan status gizi di Kecamatan Tompobulu Kabupaten Bantaeng menunjukkan bahwa remaja yang mempunyai status gizi baik $64,9 \%$ sedangkan status gizi kurang $31,1 \%$ dan status gizi buruk $4 \%$.

Beberapa fakta awal yang dikemukakan menurut hasil studi di SMP Negeri 4 Tompobulu Kecamatan Gantarangkeke Kabupaten Bantaeng adalah 53\% siswa tidak mengetahui menu seimbang dan jenis makanan yang mengandung zat gizi, dan sebanyak 33,3\% tidak makan siang setelah sampai di rumah karena di sekolah sudah jajan mie instant pada dua kali istirahat (Hendrayati, Salmiah, \& Rauf, 2010). Pengetahuan gizi pada remaja sangat penting karena setiap orang akan cukup gizi jika makanan yang dimakannya mampu menyediakan zat gizi yang diperlukan untuk pertumbuhan tubuh yang optimal, karena pengetahuan gizi memberikan informasi yang berhubungan dengan status gizi, makanan dan hubungannya dengan kesehatan (Hendrayati, Salmiah, \& Rauf, 2010).

Berdasarkan hasil penelitian yang dilakukan oleh Heriyana (2013), di Madrasah Aliyah Negeri Kota Jambi dari seluruh responden yang menjadi sampel penelitian ada 106 didapatkan hasil 6 $(5,6 \%)$ remaja berpengetahuan status gizi kurang, 18 (16,8\%) remaja berpengetahuan status gizi cukup, 82 $(76,6 \%)$ remaja berpengetahuan status gizi baik. Pengetahuan status gizi pada remaja menurut jenis kelamin didapatkan pada laki-laki yang 
berpengetahuan status gizi kurang 1 $(0,9 \%)$ siswa, berpengetahuan status gizi cukup $6 \quad(5,6 \%)$ siswa dan berpengetahuan status gizi baik 32 $(30,1 \%)$ siswa sedangkan untuk Perempuan yang berpengetahuan status gizi kurang $5(4,6 \%)$ siswa , berpengetahuan status gizi cukup 12 $(11,2 \%)$ siswa dan berpengetahuan status gizi baik $50(46,7 \%)$ siswa.

Pada usia belasan masih sering dijumpai pengertian yang kurang tepat mengenai kontribusi gizi dari berbagai makanan. Oleh karena itu, timbul berbagai penyakit-penyakit dari kesalahan gizi yang merugikan kecerdasan dan produktivitas (Ringga, 2011). Salah satu status gizi yang salah seperti kekurangan gizi dan juga kelebihan gizi.

Survey dilakukan di daerah pedesaan dan perkotaan di sekolah dan wilayah masyarakat menunjukkan tingginya prevalensi kekurangan gizi atau kurus, di wilayah pedesaan Bangladesh memiliki prevalensi tertinggi untuk gizi kurang sebanyak $67 \%$ di kalangan remaja. Pada saat yang sama, prevalensi terendah diamati pada anak sekolah perempuan dari Bangladesh di wilayah perkotaan sebesar $16 \%$. Pada anak laki-laki dan perempuan, prevalensi anak laki-laki kurus lebih banyak dari anak perempuan (75\% dan 59\%) di wilayah pedesaan Bangladesh. Prevalensi gizi kurang di Myanmar adalah $32 \%$, gizi kurang yang lebih umum pada kelompok usia 16-18 tahun 40,6\% dibandingkan dengan remaja yang lebih muda (Haider, 2006).

Prevalensi gizi lebih meningkat di seluruh populasi dunia. Tetapi distribusinya bervariasi setiap negara. Di AS, selama 30 tahun terakhir, prevalensi obesitas meningkat dari sekitar 12-20\% penduduk dari tahun 1978 sampai 1998. Negara Inggris mengalami peningkatan prevalensi obesitas dari $7 \%$ pada tahun
1980 menjadi $16 \%$ di tahun 1998. Negara-negara lain, seperti Belanda, telah mengalami peningkatan yang jauh lebih rendah dari awal sekitar 5\% pada tahun 1980 menjadi sekitar 8\% di tahun 1999.

Di Asia, prevalensi obesitas memiliki peningkatan yang cepat. Dalam 8 tahun terakhir proporsi laki-laki di Cina dengan indeks massa tubuh (BMI) 0,25 $\mathrm{kg} / \mathrm{m} 2$ menjadi tiga kali lipat $4-15 \%$ dari populasi dan proporsi perempuan menjadi dua kali lipat dari 10 sampai $20 \%$. Populasi Pasifik kemungkinan memiliki beberapa tingkat prevalensi tertinggi di dunia, proporsi laki-laki dan perempuan dengan BMI $0,30 \mathrm{~kg} / \mathrm{m} 2$ di Nauru adalah $77 \%$ dari 199.411 orang dan untuk yang tinggal di Selandia Baru pada awal 1990-an tingkat prevalensi sekitar $65-70 \%$ (Swinburn, Caterson, Seidell, \& James, 2004). Di Australia sekitar 20-25\% dari anak-anak dan remaja memiliki gizi berlebih sebesar $10 \%$ dari anak-anak di seluruh dunia (Schranz \& Tomkinson, 2013). Di Asia Tenggara, angka overweight mencapai $14 \%$ dan $3 \%$ obesitas (WHO, 2007).

Hasil Riskesdas (2008) menunjukan prevalensi status gizi anak sekolah (6-14 tahun) secara nasional dengan kategori kurus dan sangat kurus menurut IMT pada laki-laki sebesar $13,3 \%$ dan perempuan $10,9 \%$, status gizi berdasarkan umur. Menurut Riskesdas (2013), prevalensi masalah gizi lebih pada remaja umur 13-15 tahun di Indonesia sebesar $10,8 \%$, terdiri dari 8,3 $\%$ overweight dan 2,5\% obesitas. Sebanyak 13 provinsi dengan prevalensi gizi berlebih diatas nasional, yaitu Jawa Timur, Kepulauan Riau, DKI, Sumatera Selatan, Kalimantan Barat, Bangka Belitung, Bali, Kalimantan Timur, Lampung, Sulawesi Utara dan Papua. 
Prevalensi masalah gizi lebih pada remaja umur 16-18 tahun sebanyak 7,3 $\%$ yang terdiri dari 5,7\% overweight dan $1,6 \%$ obesitas. Provinsi dengan prevalensi gizi berlebih tertinggi adalah DKI Jakarta $(4,2 \%)$ dan terendah adalah Sulawesi Barat $(0,6 \%)$. Di Jawa Barat remaja berumur 13-15 tahun sebanyak $9,8 \%$ terdiri dari $7,8 \%$ overweight dan $2 \%$ obesitas. Sedangkan pada remaja berumur 16-18 tahun sebanyak 7,6\% terdiri dari $6,2 \%$ overweight dan $1,4 \%$ obesitas (Riskesdas, 2013).

Berdasarkan studi pendahuluan yang dilakukan di beberapa sekolah diantaranya yaitu SMPN 31, SMPN 37 dan SMPN 40 Kota Bandung. Dari ketiga SMPN tersebut siswa-siswi yang memiliki kriteria IMT beragam yaitu lebih banyak didapatkan di SMPN 40 sehingga peneliti mengambil sekolah tersebut untuk dijadikan tempat penelitian. Setelah dilakukan wawancara pada 9 siswa-siswi dengan kondisi status gizi yang beragam. Ada 2 orang yang berstatus gizi kurang yaitu memiliki IMT 17,3 sampai 18, status gizi baik ada 4 orang dengan rata-rata memiliki IMT 18 sampai 24,2 dan ada 3 orang yang memiliki status gizi lebih dengan IMT lebih dari 29,3.

sejumlah tiga siswa dan siswi yang mengatakan selalu jajan makanan yang berlemak, pedas, asam dan mereka jarang memakan sayuran atau buahbuahan di rumahnya karena orang tuanya bekerja setiap hari sehingga tidak sepenuhnya memperhatiakan asupan makanan yang mereka konsumsi, ada juga orang tuanya yang kurang memperhatikan asupan makanan anaknya dikarenakan faktor ekonomi. Setiap hari mereka selalu diberikan uang saku sebesar sepuluh ribu hingga dua puluh lima ribu rupiah.

Mereka tidak mengerti apa dampak yang bisa muncul dari makanan yang mereka makan setiap hari, mereka hanya tahu bila makan banyak bisa menyebabkan kegemukan pada tubuh mereka dan bila kurang makan maka akan menyebabkan kurus. Sejumlah dua siswa yang tidak mengetahui status gizinya sendiri mereka mengatakan bahwa tidak tahu termasuk pada golongan overweight, obesitas, atau kurus. Siswa tersebut tidak memperdulikan akan tubuhnya karena mereka selalu berolahraga sehingga tidak khawatir menjadi overweight atau obesitas. Setiap hari siswa-siswi hanya berkativitas di sekolah seperti kegiatan olahraga yang diadakan satu minggu sekali dan ada juga siswa yang rutin mengikuti kegiatan olahraga futsal, basket sehabis pulang dari sekolah. Berdasarkan fenomena diatas peneliti melakukan lebih lanjut terkait penelitian tentang gambaran pengetahuan remaja tentang status gizi di SMPN 40 Kota Bandung.

\section{METODE PENELITIAN}

Jenis penelitian yang digunakan dalam penelitian ini adalah penelitian kuantitatif, dengan desain penelitian deskriptif dengan pendekatan cross sectional. Populasi dalam penelitian ini adalah seluruh remaja SMPN 40 Bandung. Jumlah murid laki-laki 419 dan 356 perempuan. Penentuan jumlah sampel dengan menggunakan rumus Proporsional Random Sampling, didapatkan jumlah sampel sebanyak 89 siswa-siswi. Instrumen pengetahuan gizi berupa pertanyaan yang terdiri dari 30 soal, dengan pilihan multiple choice. Responden memilih antara 4 jawaban alternatif a, b, c atau d dengan memberikan tanda (X) pada jawaban yang benar. Penilaian kuesioner pengetahuan status gizi dilakukan dengan memberi skor, bila jawaban salah akan diberi nilai 0 dan jawaban yang benar akan diberi nilai 1 sehingga skor minumum 0 dan skor maksimum 30 dan 
dikategorikan menjadi tingkat pengetahuan remaja yakni baik, cukup, dan kurang.

\section{HASIL PENELITIAN}

Data pertama yang didapatkan dari responden yaitu jenis kelamin yang prosentase nya hampir sama antara lakilaki $(49,4 \%)$ dan perempuan $(50,6 \%)$. Rentang usia siswa setengahnya berusia 13 tahun $(55,1 \%)$.

Penelitian ini menggambarkan hasil pengetahuan gizi secara umum dan juga dispesifikan dalam beberapa bagian, diantaranya : Gambaran pengetahuan status gizi, pengetahuan tentang gizi lebih, pengetahuan tentang gizi kurang, pengetahuan penilaian gizi, faktor-faktor yang mempengaruhi status gizi.

Tabel 1

Distribusi Frekuensi Pengetahuan Gizi $(n=89)$

\begin{tabular}{ccc}
\hline Kategori & Frekuensi & Persentase \\
\hline Baik & 48 & $53,9 \%$ \\
Cukup & 22 & $24,7 \%$ \\
Kurang & 19 & $21,3 \%$ \\
\hline Total & $\mathbf{8 9}$ & $\mathbf{1 0 0 \%}$ \\
\hline
\end{tabular}

Tabel 1 menunjukan bahwa sebagian besar responden berpengetahuan baik yaitu sebanyak 48 orang $(53,9 \%)$. Sebagian kecil responden berpengetahuan cukup yaitu sebanyak 22 orang $(24,7 \%)$ dan responden berpengetahuan kurang yaitu sebanyak 19 orang $(21,3 \%)$.

Tabel 2

Distribusi Frekuensi Pengetahuan Status

\begin{tabular}{|c|c|c|c|c|}
\hline \multicolumn{5}{|c|}{ Gizi (n=89) } \\
\hline Item Soal & $\boldsymbol{F}$ & $\%$ & $\begin{array}{c}\text { Kategori } \\
\text { Pengetahuan }\end{array}$ & Persentas \\
\hline Soal No.1 & 74 & 83,1 & Baik & $83,1 \%$ \\
\hline Soal No.17 & 67 & 75,3 & Baik & $75,3 \%$ \\
\hline Soal No.18 & 61 & 68,5 & Cukup & $68,5 \%$ \\
\hline Soal No.22 & 69 & 77,5 & Baik & $77,5 \%$ \\
\hline Soal No. 24 & 51 & 57,3 & Cukup & $57,3 \%$ \\
\hline
\end{tabular}

Tabel 2 menunjukan bahwa nilai tertinggi yang didapatkan responden paling tinggi di soal no.1 terkait pengertian status gizi, dan nilai paling rendah dari item soal no 24 terkait kategori status gizi.

Tabel 3

Distribusi Frekuensi Pengetahuan Status Gizi Lebih $(\mathrm{n}=89)$

\begin{tabular}{ccccc}
\hline Item Soal & $\boldsymbol{F}$ & $\%$ & $\begin{array}{c}\text { Kategori } \\
\text { Pengetahuan }\end{array}$ & Persentase \\
\hline Soal No. 2 & 81 & 91,0 & Baik & $91,0 \%$ \\
Soal No. 3 & 85 & 95,5 & Baik & $95,5 \%$ \\
Soal No. 4 & 70 & 78,7 & Baik & $78,7 \%$ \\
Soal No. 5 & 81 & 91,0 & Baik & $91,0 \%$ \\
Soal No.16 & 71 & 79,8 & Baik & $79,8 \%$ \\
Soal No. 21 & 51 & 57,3 & Cukup & $57,3 \%$ \\
\hline
\end{tabular}

Tabel 3 menunjukan bahwa nilai tertinggi yang didapatkan responden paling tinggi di soal no.3 terkait pengertian obesitas, dan nilai paling rendah dari item soal no 21 terkait makanan penyebab obesitas.

Tabel 4

Distribusi Frekuensi Pengetahuan Status Gizi Kurang ( $\mathrm{n}=89)$

\begin{tabular}{ccccc}
\hline Item Soal & $\boldsymbol{F}$ & $\%$ & $\begin{array}{c}\text { Kategori } \\
\text { Pengetahuan }\end{array}$ & Persentase \\
\hline Soal No. 9 & 67 & 75,3 & Cukup & $75,3 \%$ \\
Soal No.10 & 71 & 79,8 & Baik & $79,8 \%$ \\
Soal No.11 & 74 & 83,1 & Baik & $83,1 \%$ \\
Soal No.14 & 70 & 78,7 & Baik & $78,7 \%$ \\
Soal No.15 & 56 & 62,9 & Cukup & $62,9 \%$ \\
Soal No.20 & 57 & 64,0 & Cukup & $64,0 \%$ \\
\hline
\end{tabular}

Tabel 4 menunjukan bahwa nilai tertinggi yang didapatkan responden paling tinggi di soal no.11 terkait dampak kekurangan zat besi, dan nilai saling rendah dari item soal no 15 terkait dampak kekurangan protein.

\section{Tabel 5}

Distribusi Frekuensi Pengetahuan Penilaian 


\begin{tabular}{cccccccc}
\hline Item Soal & $\boldsymbol{F}$ & $\%$ & $\begin{array}{c}\text { Kategori } \\
\text { Pengetahuan }\end{array}$ & $\begin{array}{c}\text { Persentas@elanjutnya } \\
\text { responden pada penelitian ini yaitu }\end{array}$ \\
\hline Soal No. 6 & 53 & 59,6 & Cukup & $59,6 \%$ & berumur 13 tahun sebanyak 49 orang \\
Soal No. 8 & 31 & 34,8 & Kurang & $34,8 \%$ & $(55,1 \%)$. Umur 12 sampai 15 tahun \\
\hline
\end{tabular}

Tabel 5 menunjukan bahwa nilai tertinggi yang didapatkan responden paling tinggi di soal no.6 terkait alat ukur status gizi, dan nilai paling rendah dari item soal no 8 terkait AKG.

Tabel 6

Distribusi Frekuensi Pengetahuan Faktor yang Mempengaruhi Status Gizi $(\mathrm{n}=89)$ merupakan remaja awal yang ingin mengetahui tentang semua hal-hal baru yang ada di sekitar mereka dan cenderung meniru. Umur akan mempengaruhi pengalaman seseorang, semakin tinggi umur maka diharapkan mempunyai pengetahuan yang lebih baik (Wawan, 2011).

Hasil penelitian menunjukan pengetahuan status gizi yang diukur dari

\begin{tabular}{ccccc}
\hline Item Soal & $\boldsymbol{F}$ & $\%$ & $\begin{array}{c}\text { Kategori } \\
\text { Pengetahuan }\end{array}$ & $\begin{array}{c}\text { Persentasemampuan, } \\
\text { pertanyaan yang berkaitan dengan status }\end{array}$ \\
\hline Soal No.7 & 54 & 60,7 & Cukup & $60,7 \%$ gizi secara umum. Pengetahuan dalam \\
Soal No.12 & 72 & 80,9 & Baik & $80,9 \%$ gizi \\
Soal No.13 & 61 & 68,5 & Cukup & $68,5 \%$ penelitian ini ada tiga kategori yaitu \\
Soal No.19 & 63 & 70,8 & Cukup & $70,8 \%$ baik, cukup, kurang. Pengetahuan yang \\
Soal No.23 & 58 & 65,2 & Baik & $65,2 \%$ dimiliki siswa-siswi akan berbeda-beda.
\end{tabular}

Tabel 6 menunjukan bahwa nilai tertinggi yang didapatkan responden paling tinggi di soal no.12 terkait pengaruh aktifitas fisik, dan nilai paling rendah dari item soal no 8 terkait angka kecukupan gizi.

\section{PEMBAHASAN}

Sebagian besar responden pada penelitian ini adalah perempuan sebanyak 45 orang $(50,6 \%)$. Menurut Hurlock (1994), pada usia remaja terjadi perubahan bentuk tubuh dan perkembangan secara psikologis dan reproduksi. Secara psikologis, anak perempuan mulai memperhatikan penampilan dan bentuk tubuhnya sehingga sangat besar kemungkinan munculnya persepsi body image. Sehingga pada remaja perempuan penampilan dan bentuk tubuh merupakan hal yang penting dibandingkan laki-laki.
Hasil data yang diperoleh peneliti pada pengisian kuesioner pengetahuan status gizi didapatkan nilai yang beragam yaitu baik, cukup, kurang.

Sebagian besar responden tergolong dalam kategori memiliki pengetahauan baik yaitu 48 orang (53,9\%), sebagian kecil responden berpengetahuan cukup yaitu sebanyak 22 orang $(24,7 \%)$ dan responden berpengetahuan kurang yaitu sebanyak 19 orang $(21,3 \%)$. Penelitian ini didukung oleh penelitian yang dilakukan oleh Epridiawati tentang hubungan pengetahuan gizi dengan status gizi siswa SMP di kecamatan kerja kabupaten karanganyar tahun 2012. Hasilnya didapatkan bahwa hampir seluruh responden remaja berpengetahuan status gizi baik yaitu 153 responden $(85 \%)$.

Pengetahuan (knowledge) adalah hasil tahu dari manusia, yang sekedar menjawab pertanyaan apa sesuatu itu. Pengetahuan dapat salah atau keliru, karena bila pengetahuan ternyata salah atau keliru maka tidak dapat dianggap 
sebagai pengetahuan (Notoatmojo, 2010). Pengetahuan status gizi seseorang dapat diperoleh melalui pendidikan formal dan informal. Pendidikan formal ialah melalui kurikulum yang diterapkan di sekolah. Dicirikan dengan adanya tingkatan kronologis yang ketat untuk tingkat usia sasarannya. Sementara pendidikan informal tidak terorganisasi secara struktural dan tidak mengenal tingkatan kronologi menurut usia, keterampilan, dan pengetahuan, tetapi terselenggara setiap saat di lingkungan sekitar manusia (Hayati 2000).

Pengetahuan gizi menjadi andalan yang menentukan konsumsi makanan. Individu yang memiliki pengetahuan gizi baik akan mempunyai kemampuan untuk menerapkan pengetahuan status gizinya dalam pemilihan maupun pengolahan makanan, sehingga konsumsi makanan mencukupi kebutuhan (Amelia, 2008). Pengetahuan akan memberikan pengaruh secara tidak langsung terhadap status gizi (Epridawati, 2012).

Status gizi yaitu keadaan keseimbangan dalam bentuk variabel tertentu, atau perwujudan dari nutriture dalam bentuk variabel tertentu contohnya seperti gondok endemik merupakan keadaan tidak seimbangnya atau kurangnya pemasukan dan pengeluaran yodium dalam tubuh, hal inilah yang bisa menyebabkan malnutrisi seperti under nutriton, specific defisiency, over nutriton dan imbalance (Wati \& Proverawati, 2010). Status gizi bisa menyebabkan masalah gizi lebih, disebabkan oleh kebanyakan masukan energi dibandingan dengan pengeluaran energi, mengakibatkan remaja menjadi kelebihan gizi seperti overweight dan obesitas (Pandu, 2014).

Selain itu, adapun banyak faktor yang bisa mempengaruhi pengetahuan dan status gizi seseorang salah satunya adalah aktivitas fisik mempunyai pengaruh terhadap kejadian obesitas semakin banyak aktivitas maka semakin banyak kalori yang digunakan sehingga tubuh menjadi ideal atau justru lebih kurus, tetapi apabila kurang beraktivitas tubuh akan cenderung menyimpan kelebihan kalori sehingga terjadi kelebihan berat badan atau gizi berlebih (Epridawati, 2012). Tingkat pendidikan dan ekonomi orang tua sangat mempengaruhi status gizi anak. Semakin tinggi tingkat pendidikan orang tua maka semakin tinggi pengetahuannya tentang gizi, semakin tinggi ekonomi keluarga maka semakin mudah mendapatkan makanan yang bergizi yang mampu meningkatkan atau mencukupi kebutuhan gizi seorang anak (Mutmainnah, Dachlan, \& Nawir, 2013).

Kebiasaan mengonsumsi pangan yang nutrisinya kurang, seperti fastfood dapat menganggu status gizi seseorang karena dapat menyebabkan obesitas, resiko terkena hipertensi dan penyakit degeratif lain. Faktor lain yang mempengaruhi status gizi adalah kecenderungan semakin sering merokok dan semakin banyak jumlah rokok yang dihisap maka semakin buruk status gizinya (Epridawati, 2012).

\section{KESIMPULAN}

Hasil penelitian yang telah dilakukan di SMPN 40 Kota Bandung tentang gambaran pengetahuan remaja tentang status gizi didapatkan kesimpulan sebagian besar responden berjenis kelamin perempuan berjumlah 45 orang $(50,6 \%)$ dan sebagian besar responden memiliki umur yaitu 13 tahun berjumlah 49 orang $(55,1 \%)$. Kategori Pengetahuan tentang Status Gizi Remaja baik yaitu sebanyak 48 orang $(53,9 \%)$, cukup yaitu sebanyak 22 orang $(24,7 \%)$ dan 
responden berpengetahuan kurang sebanyak 19 orang $(21,3 \%)$.

Poin tertinggi dari semua kategori didapatkan pada kategori tentang status gizi lebih yaitu hampir seluruh responden berpengetahuan baik pada sebanyak 5 pertanyaan atau $(83,3 \%)$ terutama terkait pengertian obesitas. Poin terendah dari semua kategori didapatkan pada kategori penilaian status gizi yaitu setengah dari responden berpengetahuan kurang pada pertanyaan pengukuran status gizi.

\section{Saran}

Disarankan bagi sekolah untuk dapat lebih memperhatikan dan memberikan pendidikan khususnya pendidikan tentang gizi dan status gizi di sekolah untuk meningkatkan pengetahuan siswasiswi. Pihak sekolah diharapkan dapat berpartisipasi peduli status gizi bagi para siswa-siswinya dengan selalu menerapkan pola makan yang cukup dan sehat di lingkungan sekolah serta memfasilitasi kantin sehat agar siswasiswi bisa mengkonsumsi makanan yang dibutuhkan oleh tubuh dan memiliki gizi yang cukup.

\section{DAFTAR PUSTAKA}

Ali, M., \& Asrori, M. (2011). Psikolgi remaja perkembangan peserta didik. Jakarta : Bumi Aksara.

Almatsier, S. (2009). Prinsip dasar ilmu gizi. Jakarta: Gramedia Pustaka Utama.

Amelia, F. (2008). Konsumsi pangan, pengetahuan tentang gizi, status gizi dan aktivitas fisik di kota sungai penuh kabupaten kerinci provinsi jambi. Bogor Agricultural University, 1-79.

Arikunto, S. (2013). Prosedur penelitian suatu pendekatan praktik. Jakarta: Rineka Cipta.
Bararah, T., \& Jauhar, M. (2013). Asuhan keperatan pandun lengkap menjadi perawat profesional. Jakarta: Prestasi Pustaka.

Dewi, S. R. (2013). Hubungan antara pengetahuan gizi, sikap terhadap gizi dan pola konsumsi siswa xii program keahlian jasa boga di smk negeri 6 yogyakarta. Universitas Negeri Yogyakarta, $1-142$.

Dharma, K. K. (2011). Metodologi penelitian keperawatan panduan melaksanakan dan menerapkan hasil penelitian. Jakarta: CV. Tans Info Media.

Epridawati, D. D. (2012). Hubungan pengetahuan tentang gizi dengan status gizi siswa smp di kecamatan kerjo kabupaten karanganyar. Fakultas Kedokteran Universitas Muhammadiyah Surakarta, 1-17.

Haider, R. (2006). Adolescent nutrition:a review of the situation in selected south-east asian countries. World Health Organization, 1-96.

Hendrayati, Salmiah, \& Rauf, S. (2010). Pengetahuan status gizi lebih dan kurang, pola makan dan status gizi siswa smp negeri 4 tompobulu kabupaten bantaeng . Media Gizi Pangan, Vol. IX, Edisi 1, 1-8.

Hurlock EB. 1994. Psikologi perkembangan. Jakarta: Erlangga.

Hurlock, E. B. (1980). Psikologi perkembangan suatu pendekatan sepanjang rentang kehidupan. Jakarta: Erlangga.

Mutmainnah, Dachlan, D., \& Nawir, N. (2013). Gambaran pengetahuan umum gizi olahraga pelatih dan status gizi antropometri siswa sekolah sepak bola di makassar. Komite Olahraga Nasional 
Indonesia Daerah Sulawesi Selatan, 1-16.

Notoatmojo, S. (2010). Metodologi penelitian kesehatan. Jakarta: Asdi Mahastaya.

Paath, E. F., Rumdasih, Y., \& Heryati. (2005). Gizi dalam kesehatan reproduksi. Jakarta: EGC.

Pandu, S. Y. (2014). Konsep diri remaja putri yang mengalami obesitas. Psikovidya Volume 18 Nomor 2 , 1-25.

Prameswar, S. P., Aisah, S., \& Mifbakhuddin. (2013). Hubungan obesitas dengan citra diri dan harga diri pada remaja putri di kelurahan jomblang kecamatan candisari semarang. Jurnal Keperawatan Komunitas, 52-61.

Ringga, M. (2011). Studi tentang pengetahuan gizi, kebiasaan makan, aktivitas fisik, status gizi dan body image remaja putri yang berstatus gizi normal dan gemuk/obes di sma budi mulia bogor. Bogor Agricultural University, 1-79.

Santrock, John W. (2007). Remaja. Jakarta: Erlangga.

Schranz, N., \& Tomkinson, G. (2013). What is the effect of resistance training on the strength, body composition and psychosocial status of overweight and obese children and adolescents a systematic review and metaanalysis. Springer International Publishing Switzerland, 893907.

Swinburn, B., Caterson, I., Seidell, J., \& James, W. (2004). Diet, nutrition and the prevention of excess weight gain and obesity. Public Health Nutrition, 123-146.

Wahyuni, D., \& Rahmadewi. (2011). Kajian profil penduduk remaja . Pusat Penelitian dan
Pengembangan KependudukanBKKBN, 1-4.

Wati, E. K., \& Proverawati, A. (2010). Ilmu gizi untuk kepewatan dan gizi kesehatan. Yogyakarta: Mutia Medika.

Wawan. (2011). Teori dan pengukuran pengetahuan sikap dan perilaku manusia. Yogyakarta: Nuhu Medika.

Yusuf, S., \& Sugandhi, N. M. (2011). Perkembanga perserta didik. Jakarta: Rajagrafindo Persada. 